\title{
Investigating the influence of consumer socio-demographic characteristics on the preferred type of consumption experience*
}

\author{
Agnieszka Kacprzak, Katarzyna Dziewanowska**
}

\begin{abstract}
The aim of the study was to investigate the influence of consumers' socio-demographic characteristics on their preferred types of experiences. A quantitative study (CATI) on a representative sample of 1045 Polish consumers was conducted to achieve the research objective. The results of the study show that Polish consumers are interested mostly in immersive and passive participation in consumption experiences. Demographic variables such as gender, age, income and place of residence appear to have a statistically significant influence on the preferred type of consumption experience. The conducted research contributes to the discussion on understanding the dimensions of the consumer experience.
\end{abstract}

Keywords: experience marketing, experience realms (4Es), socio-demographic variables, Poland

JEL codes: M31, M37, D4

\section{Introduction}

The experience economy is a new paradigm in marketing that places customer experiences in the centre of attention. As Maklan and Klaus (2011) noted, in recent years, the interest of marketing theorists and practitioners has shifted from fast-moving consumer goods towards building relationships based on services and has finally rested on the creation of captivating and enthralling experiences. Researchers of consumer behaviour consider an experience to be a personal occurrence that often has emotional significance and is stimulated by a company via the provision of products and services (Holbrook/Hirschman 1982). It is thought to be a central element to a person's life as "life is to be produced and created, in effect, constructed through the multiple experiences in which the consumer immerses" (Firat/Dholakia 1998). Since consumer behaviour is understood as "a process during which individuals or groups select, purchase, use or dispose of products, services, ideas or experiences to satisfy needs and desires" (Solomon 2013, p. 44), consumption refers broadly to all activities undertaken by a consumer. According to Carù and Cova (2003), a consumption experience spreads over a period of time and encompasses four stages: pre-consumption,

* Received: 12.06.2017, accepted: 26.03.2019, 4 revisions

** Agnieszka Kacprzak, Dr. habil., Associate Professor, University of Warsaw, Faculty of Management, akacprzak@wz.uw.edu.pl. Main research interests: experience marketing, consumer behavior, digital and mobile marketing.

Katarzyna Dziewanowska, Dr. habil., Associate Professor, University of Warsaw, Faculty of Management, kdziewanowska@wz.uw.edu.pl. Main research interests: experience marketing, consumer behavior, value co-creation. 
purchase, core consumption and remembered consumption experiences (Arnould et al. 2002) and cannot be reduced solely to the shopping experience. Thus, in this paper, we use the term "consumption experience" to address all aspects of consumer behaviour that result in experiences.

The starting point for our analysis is Pine and Gilmore's $(1999,2011)$ concept of experience realms based on two dimensions: active/passive and absorbing/ immersive experiences. Using these dimensions, Pine and Gilmore introduce four experience realms (4Es): entertainment, educational, esthetic and escapist. The review of the current literature on the subject shows some deficiencies. First, it should be noted that most of the cited studies refer to the tourism industry (the primary sector of the experience economy), where the implementation of the principles of experience marketing is connected with a natural course of the consumer experience. Holiday trips often involve a search for unforgettable and unique experiences that can be active as well as passive. The scales to measure experiences proposed thus far are useful only in the tourism sector. This study addresses this knowledge gap by going beyond the tourism sector and focuses also on the so-called "secondary sector" of the experience economy. Sundbo and Baernhold (2007: 11) define "the secondary sector" of the experience economy as companies for which the production of experiences is not the primary goal, but rather something added to their basic products and services, such as manufacturing, retail, and public sector companies. Experiences are also crucial for companies outside the creative, primary sectors because all of them have to deal with customer relations (Sundbo 2009). Researchers postulate to broaden the scope of the experience marketing beyond the tourism and other creative sectors of the economy as the basic assumption of this concept is that offering the consumer an opportunity to participate in a unique and unforgettable experience will increase the value of the market offer in all types of businesses (Smidt-Jensen et al. 2009, Pine/Gilmore 2011). The scale for measuring the consumer experience presented in this paper is universal and can be used in various consumption contexts, as the items refer to general consumer attitudes towards the experience.

Second, this study was conducted on a large, randomly chosen, representative sample of Polish society, which allows us to show the influence of socio-demographic variables on the consumer's preference towards active/passive and absorbing/immersing experiences. Consumers' demographics might be considered the oldest set of characteristics used for segmentation purposes (Wedel/Kamakura 2003), but new research in this field is always needed (Shukla et al. 2013). The first reason for the need for new research is the rapidly changing society, which brings changes in gender roles and symbols of social status and new generations with their own values and beliefs. As Kotler et al. (2017) emphasize, there is a need to redefine old demographic segmentations because, in the digital context, age and gender roles are changing. The above factors suggest that many studies on consumer demographics conducted in the $1970 \mathrm{~s}$ or $1980 \mathrm{~s}$ may be 
outdated, and their results are often no longer valid (Diamantopoulos et al. 2003, Pedrini/Ferri 2014). The second reason is that demographic features are usually used only as controlled variables in most of the studies. This trend is the result of sampling limitations existing in most consumer studies, such as the use of small, undifferentiated and often student samples, which are non-representative for the whole society. Moreover, the majority of studies focusing on socio-demographic characteristics of consumers in the context of experience marketing are based in the USA (Diamantopoulos et al. 2003, Shukla et al. 2013). Although European academic research in the field of experience marketing has developed significantly (Ferreira/Teixeira 2013), the research results are often not published in English. Finally, most companies that offer consumer products and services use market segmentation based primarily or solely on socio-demographic variables (Diamantopoulos et al. 2003, McDonald/Dunbar 2012) because they are more readily available, more accessible and can be applied to segmentation with relative ease in comparison to other segmentation variables (Myers 1996). Additionally, demographic characteristics are often applied to increase the accessibility of segments, as the media usage profiles are usually linked with them (Wedel/Kamakura 2003). Since this study uses a large, heterogeneous, stratified, randomly chosen sample of Polish consumers, it can yield valid results about consumers' demographics.

These contributions are important within the field of experience marketing at both the academic and practitioner levels. The analysis of characteristics that may influence consumer perceptions of different types of experiences will deepen our understanding of the relationships between the features of the market offer and consumer willingness to engage in the consumption experience. Although some studies exploring these relations can be found (Hart et al. 2007, Deshwal 2016), many of them suffer from sampling limitations, and therefore, more efforts are required to find further evidence in this field. Additionally, as companies explore new possibilities of differentiation among competitors, this study will help them to better adjust the offered type of experience to expectations of the chosen market segment. Therefore, we ask the following research question: what is the relation between the preferred type of consumption experience and the consumer demographic profile?

The rest of this paper is structured as follows: in Section 2, a review of the relevant literature is undertaken, after which, in Section 3, the conceptual framework is presented, and the research hypotheses are developed. In Section 4, the methodology implemented in the study is described. Section 5 reports the results, followed by a discussion in Section 6 . The conclusions, managerial implications, limitations and further research directions are presented in Section 7. 


\section{Literature review}

\subsection{The experience economy}

Although the consumer experience is not a new phenomenon, the emergence of the concept of the experience economy has recently led to the recognition of the consumer experience as a basis of the market offering, and researchers have focused on studying it from both academic and managerial perspectives. Despite its fairly short history, the experience economy concept has already undergone some transformations, and currently, two generations can be distinguished. The first generation of the experience economy concept was introduced by Pine and Gilmore (1999), according to whom experiences should be initiated and carefully staged by companies, while consumers are simply recipients and have little control over what is offered to them. The second generation of the experience economy concept has a different view on the consumer's role in the experience: it is assumed that people can openly communicate to companies what they want to receive (Boswijk et al. 2007). This assumption means that consumers and companies are partners involved in an open dialogue who share responsibility for outcomes of the experience (Christensen 2013). This new generation of the experience economy concept is a basis for the co-creation of experiences and value that involves the consumer and the company (Vargo/Lusch 2008, Verleye 2015, Heinonen et al. 2013). Thus, the company's role is limited to being a guide, and the customer becomes an actual creator of the experience (Boswijk et al. 2007).

Since the experience economy is both a scientific and managerial concept (Sundbo/Sorensen 2013), there have been attempts to designate its sectoral scope. Sundbo and Baerenholdt (2007) distinguished two sectors: the primary and the secondary sectors. The primary sector comprises industries whose main goal is the actual production of experiences (e.g., tourism and entee. g.nment), and it has been in the centre of attention of the experience economy since its origin (Pine/Gilmore 1999, 2011). The secondary sector includes companies pursuing different goals, and consumer experiences are used instrumentally as an addon feature increasing the value for the consumer. There is a growing body of research on this sector, and it provides evidence that consumers are more ready to embrace the co-creation of experiences in all of their activities (Schmitt 1999, Pullman/Gross 2004, Verhoef et al. 2009, Brakus et al. 2009, Zhang et al. 2015, Mahmoud et al. 2016).

\subsection{Classifications of consumer experience}

In the literature on the subject, many different classifications of consumer experiences have been proposed. The initial classifications were quite simple, such as the distinction between ordinary and extraordinary experiences (Abrahams 1986) or the division of experiences into fantasies, feelings and fun (Holbrook/ 
Hirschman 1982). Later, more complex, multidimensional classifications were developed, such as O'Sullivan and Sprangler's (1998) sixteen combinations of the experience grouped around the axes of reality and virtuality, originality and mediocrity, mass production and customization and the level of intensity of the interaction with other people.

Some of the typologies resulting from the research on a particular type of experience and their versatility are not empirically verified, such as Arnould and Price's (1993) dimensions of river floating experiences (communion with nature, communities, personal growth and renewal of self), Otto and Ritchie's (1996) dimensions of tourism services experiences (hedonism, interactivity, novelty/ originality, comfort, safety and stimulation) and Zhao and Dong's (2013) types of automotive experiences (achievement, spiritual, sensory, and emotional).

Other typologies are of a conceptual nature, and thus, their applicability seems to be broader. Based on Dewey's (1925) concept of the experience, Pinker (1997) proposed four mental modules, including sensory perception, feelings and emotions, creativity and thinking, and social relations. Schmitt (1999) is the author of a five-element set of strategic experience modules that include sensory, emotional, intellectual, behavioural, and relational aspects of the experience. This proposal was later extended by Gentile, Spiller and Noci (2007) to six components of the experience: sensory (sensual sensations), emotional (mood, emotions and feelings), cognitive (conscious mental processes), pragmatic (physical function and usability), lifestyle-related (values and personal beliefs), and relational (belonging to a community and social identity confirmation). The conceptual nature is also characteristic of the experience realms model proposed by Pine and Gilmore $(1999,2011)$, which was selected for the purpose of this study. Typologies based on experience modules, such as those of Pinker (1997), Schmitt (1999) and Gentile, Spiller and Noci (2007), have been applied to the secondary sector of the experience economy (Brakus et al. 2009, Choi et al. 2016, Japutra/Molinillo 2018, Sheng/Teo 2012, Nysveen/Pedersen 2014, Zarantonello/Schmitt 2010, Ishida/Taylor 2012), while the four realms model of Pine and Gilmore $(1999,2011)$ has been primarily used primarily in the primary sector context (Lo et al. 2013). As this model is comprehensive, intuitive and therefore attractive from a practical perspective, we believe that more knowledge about the general preferences of consumers towards experience realms is needed for the design of a market offer that provides desired experiences.

\subsection{Concept of experience realms (4E)}

This concept classifies the experiences that can be provided to consumers into four types according to the level of activity required of the consumer and the level of immersion in the offered experience. The degree of activity reflects the extent to which a consumer in a given situation is expected to remain only a pas- 
sive observer and the extent to which he or she is to become an active participant (Pine/Gilmore 2011). At a low level of participation, the consumer has no influence over the course of the experience, whereas at a high level of participation, he or she can actively affect its scenario (Caru/Cova 2003). In turn, the degree of immersion refers to the link between the consumer and the experience. Absorption, as a state opposite to immersion, assumes that the consumer remains a distant observer, while immersion means physical or virtual engagement in the offered experience. Immersive experiences also offer the possibility to influence the course of the experience, while absorption instead involves simple acceptance of what is provided. These dimensions are shown in Figure 1.

\section{Figure 1. Experience realms}

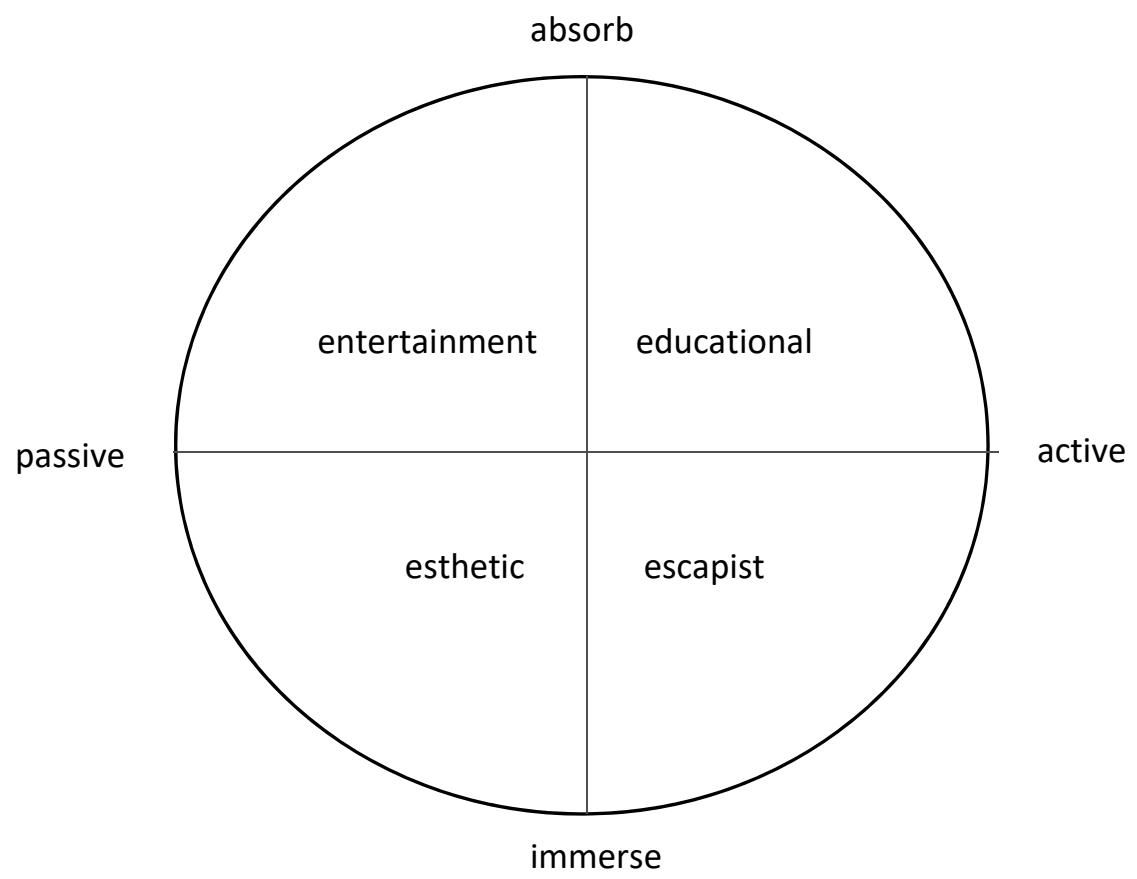

Source: Pine and Gilmore (2011, p. 46)

The authors of this concept (Pine/Gilmore 2011, pp. 47-56) describe the entertainment experience as an experience in which consumers participate in a passive way and that is associated with absorption. Participants in these experiences absorb the events through their senses without engaging in them (e.g., watching TV). The aim of participation is good fun that does not require too much activity and commitment. In turn, the esthetic experience allows consumers to immerse themselves in sensations but does not require active participation on their part. 
An example would be a tourist admiring a mountain view or a person looking at a masterpiece in an art gallery. The aim of participation in this type of experience is simply to be and to lose oneself in the appreciation of what one sees. The third type of experience, the educational experience, requires active participation, but consumers themselves do not have much impact on its course. It can be, for example, attending a lecture or a snowboarding lesson. The goal of a participant is to learn something or to develop new skills. Finally, the escapist experience requires consumers to both immerse themselves in the experience and to actively influence its course. An example of such an experience is a person playing a computer game who creates his or her own character and controls its adventures while forgetting about the rest of the world. The goal of the participant is to "go into the experience and do something" (Pine/Gilmore 1999, p. 31).

Pine and Gilmore $(1999,2011)$ claim that while various combinations of the above realms are possible (e. g., edutainment $=$ education + entertainment, escasthetic $=$ escapist + esthetic $)$, an ideal consumer experience lies in the centre of all the realms and incorporates education, entertainment, esthetic and escapist aspects of the experience. However, do all consumers want to actively participate and immerse themselves in experiences offered by commercial companies, as Pine and Gilmore $(1999,2011)$ assume? Perhaps simple entertainment is enough for some of them. Pine and Gilmore (1999) believed it is best to engage all four areas in the creation of a single offer. In their opinion, locating an offer in the middle of the framework, the so-called 'sweet spot', allows the attainment of the richest and most positively perceived experience. However, some of the recent research undermines this assumption, showing that each consumer might prefer a single experience realm according to the level of activeness and immersion he or she would like to achieve in a consumption context (Jeong et al. 2009, Oh et al. 2007).

\subsection{Existing studies on the experience realms concept}

The existing studies on experience realms can be divided into three categories: conceptual/theoretical, qualitative and quantitative (developing or applying scales for quantitative measures of the experience realms) (see Table 1).

Table 1. Literature review - studies exploring the experience realms (4Es) concept

\begin{tabular}{|c|c|c|}
\hline Type of study & Author(s)/year & Experience economy sector \\
\hline Conceptual/theoretical & Nijboer (2006) & First (libraries) \\
& Atwal and Williams (2009) & First (luxury brands) \\
& Quadri-Felitti and Fiore (2012) & First (tourism) \\
& Leung et al. (2013) & First (tourism) \\
& Seo (2013) & First (e-sports) \\
\hline
\end{tabular}




\begin{tabular}{|c|c|c|}
\hline Type of study & Author(s)/year & Experience economy sector \\
\hline $\begin{array}{c}\text { Based on qualitative } \\
\text { research }\end{array}$ & Gram (2011) & First (theme parks) \\
& $\begin{array}{c}\text { Iyanna et al. (2012) } \\
\text { Petermans et al. (2013) }\end{array}$ & $\begin{array}{c}\text { Second (retail shops) } \\
\text { Lo et al. (2013) }\end{array}$ \\
\hline $\begin{array}{c}\text { Based on quantitative } \\
\text { research }\end{array}$ & First (tourism) \\
& Pikket al. (2007) & First (tourism) \\
& Jurkowski (2009) & First (tourism) \\
& Jeong et al. (2009) & First (tourism) \\
& Hosany and Witham (2010) & Second (apparel) \\
& Fulgsang et al. (2011) & First (tourism) \\
& Keng et al. (2014) & First (experience services) \\
& Manthieu et al. (2014) & First (summer festivals) \\
\hline
\end{tabular}

Source: own research

Conceptual papers emphasize the holistic nature of the experience and show how to apply the concept of the four experience realms in a chosen consumption context. For example, Nijboer (2006) considers the approach of libraries in the implementation of the 4Es, and Leung et al. (2013) similarly describe museums. We can also find the application of this concept to building luxury brands (Atwal/Williams 2009). Seo (2013) argues that the 4Es are equally relevant and useful in understanding the experiential value of eSports. The 4Es model was also used by Quadri-Felitti and Fiore (2012) for conceptualizing the wine tourism experience. Due to the theoretical nature of these studies, their main contribution is limited to the determination of the directions of further research and showing the possible managerial implications in a certain economy sector.

The second category of research is based on qualitative studies. Gram (2011) examined a 40-year history of theme park ads targeting children. In her opinion, there was a shift from the view that esthetic experiences are the most appropriate for children towards a view that escapist experiences are most appropriate. The tourism sector was the subject of an investigation by Iyanna et al. (2012), who used the concept of the four realms to analyse consumer experiences during travel. They applied netnography in the form of blog analysis as a research method and found that different consumers might interpret the same experience differently, which testifies to the fact that experiences are idiosyncratic. The qualitative research conducted by Petermans et al. (2013) in the form of interviews with retail shop designers showed their attempts to address all four dimensions of the consumption experience at the same time. In their study, Lo et al. (2013) combined Pine and Gilmore's $(1999,2011)$ experience realms with Aho's 
(2001) realms of tourism experience, showing that consumers' spa experiences consisted of the realms of esthetics, education, escapism, transformation, cure, reward and recognition. However, the presence of the entertainment dimension was not confirmed. Because these studies were based on a single qualitative method, they all face the limitations common to this type of research, such as being context-specific and ungeneralizable.

The third stream of research is based on quantitative methods, and researchers either tried to develop their own scales to measure the consumer experience using the 4Es concept or applied existing scales to different consumption situations. The first and most cited study here is that by Oh et al. (2007), who developed a scale to measure the 4Es in the tourism sector (bed-and-breakfast). Each experience realm was linked with the consumer's satisfaction, arousal, memories and quality assessment. The esthetic dimension of the experience turned out to have the biggest impact on studied marketing effects, while the influence of the escapist and entertainment realms was statistically insignificant. Hosany and Witham (2010) used the same scale to measure the experiences of participants on Caribbean cruises. According to their research, similar to Oh et al. (2007), the four experience realms differ in terms of their relative importance in explaining the outcome variables of memory, arousal, overall perceived quality, satisfaction and intention to recommend. The esthetic realm is of the greatest importance, followed by the entertainment realm, which was insignificant in Oh et al.'s (2007) research. The explanation might be the different context of the research - consumers seek different experiences during a cruise than at a bed-andbreakfast. The same measurement tool was applied by Manthiou et al. (2014) in their study regarding the influence of each of the experience realms on customer loyalty in the case of a summer festival. They found that only the esthetic and entertainment realms had a statistically significant impact. Although Oh et al. (2007) verified the reliability and validity of their scale, it can be used only in the tourism sector because the proposed 16 scale items are very context-specific.

Another measurement instrument was proposed by Jeong et al. (2009) while studying the impact of the 4Es on consumer responses in apparel e-retailing. The proposed 25-item scale is reliable but also context-specific, as all of its items refer to product presentation on websites. According to the results of their analyses, the consumer does not have to come into contact with all four realms to obtain a positive effect. In the case of an examined website, the dimensions of entertainment and esthetic experiences were sufficient to evoke the consumer's pleasure and arousal, as well as the desire to re-visit the website and recommend it to others. The educational dimension had no bearing at all on the achievement of these results, and the escapist dimension influenced only the pleasure aspect.

The third measurement scale was developed by Pikkemaat et al. (2009) to estimate how the 4Es influence consumer satisfaction in the case of wine trail visi- 
tors. The survey instrument was not tested for reliability and validity because of a very small sample of participants. Again, the esthetic realm was most important in determining the consumer's satisfaction, while educational and escapist experiences were least significant.

The remaining quantitative studies that used the experience realms concept did not apply a survey instrument to measure the 4Es. Keng et al. (2014) looked at how different experience realms influence product knowledge and brand attitude in the mp3 player market. Instead of using a survey, they applied an experimental design and asked participants of the study to explore four different websites, which represented the four experiences realms. According to the results, the escapist dimension had the greatest impact on outcome variables, while the educational dimension had the smallest. Jurkowski (2009) conducted a study among visitors of one of the American theme parks. She asked the participants about activities in which they participated and divided them post hoc into the four realms. According to the obtained results, participation in one realm did not preclude participation in another opposing realm. This study did not investigate, however, whether the levels of satisfaction with participation in opposing types of experiences were similar. The study of Fulgsang et al. (2011) was conducted among companies, not consumers. As a result of the analysis of the survey, the authors found that enterprises that try to combine various experience realms in their offers were more innovative.

The literature review presented above shows that there is a lack of a scale that could be used in quantitative research in sectors other than tourism, as the existing scales to measure the 4Es match only this context (Oh et al. 2007, Pikkemaat et al. 2009). The only exception is the scale created by Jeong et al. (2009), which, in turn, is limited to the context of apparel websites. Therefore, our objective is to create a measurement scale that can be applied to consumption experiences in all contexts.

\section{Conceptual framework and hypotheses development}

The empirical research discussed above shows that the existence of the "sweet spot" as an ideal point at the intersection of all four experience realms is questionable. Each experience realm was treated separately, and the results show that their impact on outcomes such as consumer satisfaction or perceived quality may be very different (Hosany/Witham 2010, Oh et al. 2007, Jeong et al. 2009). It was suggested that in the studied consumption contexts, the companies might focus only on one or two experience realms instead of trying to deliver all of them in one offer. Therefore, we assume that it is possible to find correlations between the preferred type of experience and the consumer demographic profile. It can be particularly useful for companies to know which experience realm they should offer to which group of customers. 
Among the studies discussed above, only that of Hosany and Witham (2010) examines the influence of demographic variables on the consumer's preference for experience realms. However, it must be noted that this study was conducted on a very small sample of participants of a single Caribbean cruise. The lack of empirical research identifying the relations between demographic variables and the preferred type of consumption experience clearly shows the existence of a research gap that we will try to fill. Exploring characteristics that are connected with a preference for certain types of experiences, this paper proposes insights that deepen our understanding of the outcomes of different types of consumption experiences. Profiling consumers who favour one type of experience over another provides companies with knowledge to better target and position their offers within the chosen segment of consumers defined by gender, age, income and place of residence. To develop the hypotheses, the following paragraphs discuss former studies with regard to each socio-demographic variable and its relationship with consumers' preferences for certain types of experiences.

\subsection{Gender}

Considering gender, we assume that women tend to choose more passive experiences than men. In many societies (including Polish society), boys are socialized to be more active and girls to be more passive in all their life activities (Röder/ Mühlau 2014). Additionally, Hosany and Witham's (2010) research shows that women rate the entertainment realm, which involves passive experiences, higher than men. Women may also value immersive shopping experiences more than men. In shopping situations, men tend to be more goal-oriented, while women more often exhibit a hedonic shopping motivation (Chang et al. 2004, Davis et al. 2014). In Hosany and Witham's (2010) research, women rated the escapist realm, which involve immersive experiences, higher than men.

H1 a: Women prefer more passive experiences than men.

$H 1$ b: Women prefer more immersive experiences than men.

\subsection{Age}

In regard to age, each generation manifests different consumption patterns because they have been impacted by different external events (Schewe/Noble 2000). It is expected that younger consumers choose more active and immersive experiences than older consumers. The first argument that supports this hypothesis is that representatives of younger generations spend most of their free time on the Internet, which requires a high level of user activeness and immersion (Tapscott 2008). Young consumers also tend to engage more than members of older generations in shopping and consumption, which play an important role in their lives (Bakewell/Mitchell 2003, Eastman et al. 2013, Jackson et al. 2011). 
H2a: Older consumers prefer more passive experiences than younger consumers.

$H 2$ b: Older consumers prefer less immersive experiences than younger consumers.

\subsection{Income}

Another variable that is considered is the income level. Respondents with higher income are expected to choose more active experiences than those with lower income. Research shows that consumers with financial constraints tend to value simple ownership of material goods more than memorable shopping experiences (Tully et al. 2015, Garðarsdóttir/Dittmar 2012). On the other hand, lower-income consumers show hedonic shopping orientation in malls more often than more affluent consumers, for whom a utilitarian orientation was prevalent (Allard et al. 2009). This finding can be explained by the fact that visiting a shopping mall does not indicate a necessity to buy something - less affluent consumers often visit such places as a form of spending free time when they cannot afford other leisure activities. Additionally, the study of Hamilton (2012) shows that low-income families often engage in conspicuous consumption to achieve social approval. Higher-income consumers also tend to be more focused on time savings than money savings while shopping (Punj 2012), and thus, they may be less willing to participate in immersive shopping experiences. Additionally, in the Polish context, older consumers are often excluded from many types of consumption situations due to their deteriorated financial situation after retirement. At the same time, this group of consumers will become a substantial part of the market, thus investigating their preferences regarding consumption experiences is of great significance (Krot/Glińska 2014).

H3 a: Consumers with lower income prefer more passive experiences than those with higher income.

$H 3$ b: Consumers with lower income prefer more immersive experiences than those with higher income.

\subsection{Place of residence}

The last independent variable that we take into account is the place of residence, which is rarely investigated by western researchers (Carpenter 2008, Patel et al. 2015), as the differences between large cities and small towns are not as pronounced in developed countries as in emerging markets. As the number of stores using experience marketing techniques is limited in small towns and villages, we assume that residents of large cities prefer more active and immersive shopping experiences. In Poland, large shopping malls are mainly located in 8 major 
cities, where $71 \%$ of the retail space is located in malls, while in smaller towns with fewer than 100,000 inhabitants - only $21 \%$ of retail space is located $\%$ n shopping malls (Jones Lang LaSalle 2017)

H4 a: Consumers from smaller towns and villages prefer more passive experiences than those from larger towns.

$H 4$ b: Consumers from smaller towns and villages prefer less immersive experiences than those from larger towns.

\section{Methods}

\subsection{Participants and procedure}

The presented study is a part of a complex project analysing the determinants of the development of the experience economy in Poland. Computer-assisted telephone interviews (CATI) were conducted with a randomly selected, representative sample of 1,045 adult Polish consumers (stratified sampling technique). The characteristics of the studied sample are shown in Table 2.

Table 2. Characteristics of the research sample

\begin{tabular}{|l|l|l|l|}
\hline \multicolumn{2}{|l|}{ Variable } & N & $\%$ \\
\hline \multirow{4}{*}{ Gender } & female & 564 & $54 \%$ \\
\cline { 2 - 4 } & male & 481 & $46 \%$ \\
\hline \multirow{4}{*}{ Age } & $18-34$ & 328 & $31 \%$ \\
\cline { 2 - 4 } & $35-49$ & 249 & $24 \%$ \\
\cline { 2 - 4 } & $50-64$ & 281 & $27 \%$ \\
\cline { 2 - 4 } & 65 and more & 187 & $18 \%$ \\
\hline \multirow{4}{*}{$\begin{array}{l}\text { Household income per } \\
\text { capita }\end{array}$} & $\leq$ PLN 1,000 & 562 & $54 \%$ \\
\cline { 2 - 4 } & $>$ PLN 1,000 & 483 & $46 \%$ \\
\hline \multirow{4}{*}{\begin{tabular}{l} 
Size of population of the ofidence \\
\cline { 2 - 4 }
\end{tabular}} & up to 10,000 inhabitants & 359 & $35 \%$ \\
\cline { 2 - 4 } & 10,000 to 99,999 inhabitants & 430 & $41 \%$ \\
\cline { 2 - 4 } & 100,000 to 499,999 inhabitants & 169 & $15 \%$ \\
\cline { 2 - 4 } & above 500,000 inhabitants & 87 & $8 \%$ \\
\hline
\end{tabular}

Source: own research, $\mathrm{N}=1045$

The questionnaire consisted of 30 items using a 5-point Likert scale anchored with 1=Strongly Disagree and $5=$ Strongly Agree. Nine of the items were used to create two scales to measure the desired level of passivity and immersion (dependent variables), while demographic characteristics (age, gender, income, place of residence) serve as the independent variables. 


\subsection{Data analysis}

The statistical analyses were performed using SPSS with the AMOS module. First, the reliability and validity of a newly formed scale was tested with exploratory factor analysis (EFA), Cronbach's Alpha statistics and confirmatory factor analysis (CFA), which allowed us to determine whether the measurement items were structurally consistent with the embedded theory and a priori logic of the measurement design. As the second step, one-way analysis of variance (ANOVA) was used for hypotheses testing. Finally, to assign consumers into one of the four experience realms on the basis of their level of preference for passive and immersive experiences, a cluster analysis with the k-means procedure was performed. This non-hierarchical method is characterized by high usability of its results (Wedel/Kamakura 2003). The algorithm is designed to segment $\mathrm{n}$ items (e.g. consumers) into $k$ clusters so that each item is assigned to the cluster of closest mean. According to our theoretical concept, four initial cluster centroids were specified, as shown in Table 3. In the next step, the algorithm located the nearest centroid for each item and allocated the item to it. Distances were computed using the simple Euclidean distance. After each allocation, the updated centroid mean was calculated. These steps were repeated until no item changed clusters. The final cluster centroids are presented in Table 3.

Table 3. Initial and final cluster centroids

\begin{tabular}{|c|c|c|c|c|c|c|c|c|}
\hline \multirow{2}{*}{} & \multicolumn{9}{|c|}{ Segment } \\
\cline { 2 - 9 } & Educational & \multicolumn{2}{|c|}{ Escapism } & \multicolumn{2}{c|}{ Entertainment } & \multicolumn{2}{c|}{ Esthetic } \\
\cline { 2 - 9 } & Initial & Final & Initial & Final & Initial & Final & Initial & Final \\
\hline $\begin{array}{c}\text { Preference for passive } \\
\text { experiences }\end{array}$ & 1 & 2.71 & 1 & 2.23 & 5 & 4.15 & 5 & 4.08 \\
\hline $\begin{array}{c}\text { Preference for immer- } \\
\text { sive experiences }\end{array}$ & 1 & 2.86 & 5 & 4.41 & 1 & 2.48 & 5 & 4.38 \\
\hline
\end{tabular}

\section{Findings}

\subsection{Scale development}

Our objective was to create universal measurement scales that can be used in various consumption contexts. Therefore, instead of creating separate scales for each of the experiential realms (which by design are context-specific), we propose two scales measuring consumer preferences towards immersive and passive experiences, which constitute the two axes designating the four experience realms. Following the procedure of developing measures created by Churchill (Churchill 1979, Churchill/Peter 1984) in the first step, we specified the definition of immersive/absorbing and passive/active experiences and generated a set of 25 items measuring the preference towards these experiences on the basis of an extensive literature review. An immersive/absorbing experience is defined by 
the consumer's relation to their environment in which the experience occurs. Immersion means that the consumer becomes a part of the experience, while absorption involves being watchful and taking in the atmosphere of the experience. In turn, passive/active experiences reflect the level of consumer participation in the experience. Consequently, three experts in the field were asked to comment on the face and content validity of the created items. The purpose was to select items with the highest degree of agreement among experts. As a result, 5 items were dropped, and the wording and structure of other items were changed. A pilot study on a sample of 100 management students was performed to purify the measure, which exceeded the recommended sample size of 30 for constructing scales (Johanson/Brooks 2010). After the calculation of reliability statistics and the factor analysis, 6 items were dropped from the scales. Another pilot study on a sample of 100 management students was performed to further assess the reliability of the measure. After calculating the coefficient alphas and conducting the exploratory and confirmatory factor analyses, an additional 5 items were dropped from the scales. The final list of statements included in the scales is shown in Table 4. These items refer to consumers' tendencies to directly and actively participate in consumption experiences offered by companies and their readiness to immerse themselves in an experience and forget about the rest of the world and the passage of time. The wording of the measurement items is such that a low score on the passive participation scale implies active participation and a low score on the immersion scale implies a preference for absorption, while high scores on the passive participation and immersion scales imply a preference for passive participation and immersion, respectively. A full list of the measurement items and the justifications for their selection is presented in the Appendix (Table A).

The principal components exploratory factor analysis (EFA) with VARIMAX rotation was applied to find an adequate number of factors (Tabachnick/Fidell 2007). The KMO test value was 0.682 , and Bartlett's test of sphericity was significant $(\mathrm{p}<0.0001)$, which confirmed sampling adequacy. Analysis of a screeplot of eigenvalues and Kaiser's criterion confirmed the existence of two components reflecting preferences towards immersive and passive experiences (see the Appendix, tables B, C and D). Cronbach's alpha for the scale measuring the passivity/activity level was 0.622 and for the scale measuring the immersion/ absorption level was 0.627 , which are acceptable results for newly constructed indicators (Churchill/Peter 1984, Nunnally 1978). Moreover, the intraclass correlation (ICC) score was calculated based on the mean-rating, absolute agreement, two-way mixed-effects model. This score provides an assessment of the consistency and reproducibility of the measurements. As seen in Table 5, the values were between 0.5 and 0.75 , which indicated moderate reliability (Shrout/ Fleiss 1979). To verify the validity of the measurement model, a confirmatory factor analysis was undertaken (see Appendix, Figure 3). As shown in Table 4, 
Table 4. Scales to measure the preference for passive/active and immersive/absorbing experiences

\begin{tabular}{|c|c|c|c|c|}
\hline & & Mean & $\begin{array}{l}\text { Standard } \\
\text { Deviation }\end{array}$ & $\begin{array}{l}\text { Standardized } \\
\text { regression } \\
\text { weights }\end{array}$ \\
\hline $\begin{array}{l}\text { Item } \\
\text { number }\end{array}$ & Preference for passive experiences & & & \\
\hline P1 & $\begin{array}{l}\text { I prefer to watch from a distance than to } \\
\text { take part directly in games and contests. }\end{array}$ & 3.9847 & 1.37219 & 0.386 \\
\hline P2 & $\begin{array}{l}\text { I mostly like to spend free time relaxing in } \\
\text { the comfort of my own home. }\end{array}$ & 4.0967 & 1.36921 & 0.399 \\
\hline P3 & $\begin{array}{l}\text { I dislike it when someone tries to persuade } \\
\text { me to actively engage in some kind of en- } \\
\text { tertainment. }\end{array}$ & 3.3665 & 1.64777 & 0.495 \\
\hline P4 & $\begin{array}{l}\text { I choose such forms of entertainment that } \\
\text { do not require too much activity from me. }\end{array}$ & 3.0679 & 1.64240 & 0.645 \\
\hline \multirow[t]{2}{*}{ P5 } & $\begin{array}{l}\text { Observing other people's participation in } \\
\text { organized pastimes gives me more plea- } \\
\text { sure than participating in them myself. }\end{array}$ & 3.3627 & 1.55288 & 0.604 \\
\hline & Preference for immersive experiences & & & \\
\hline P6 & $\begin{array}{l}\text { While admiring nature, interiors and ob- } \\
\text { jects, I can completely forget about the } \\
\text { passage of time. }\end{array}$ & 3.4344 & 1.63907 & 0.432 \\
\hline P7 & $\begin{array}{l}\text { I most enjoy forms of entertainment that } \\
\text { allow me to forget about the rest of the } \\
\text { world. }\end{array}$ & 3.6890 & 1.52248 & 0.543 \\
\hline P8 & $\begin{array}{l}\text { I have a hobby that completely consumes } \\
\text { my time and attention. }\end{array}$ & 4.1330 & 1.23739 & 0.388 \\
\hline P9 & $\begin{array}{l}\text { I often get involved in activities, during } \\
\text { which I forget about the passage of time. }\end{array}$ & 3.4383 & 1.66070 & 0.855 \\
\hline
\end{tabular}

Source: own research, $\mathrm{N}=1045$

*where 1 indicates "strongly disagree" and 5 indicates "strongly agree"

standardized regression weights ranged from 0.39 to 0.64 for the passivity scale and from 0.39 to 0.86 for the immersion scale. The model fit measures were on acceptable levels $(\mathrm{CMIN} / \mathrm{df}=2.977, \mathrm{RMSEA}=0.044, \mathrm{GFI}=0.984, \mathrm{CFI}=0.953$, $\mathrm{SRMR}=0.0357$ ) (Hair et al. 2014), which indicates that the created scales are valid.

Table 5. Intraclass correlation coefficient for developed scales

\begin{tabular}{|c|c|c|c|c|c|c|c|}
\hline & \multirow{2}{*}{$\begin{array}{c}\text { Intraclass } \\
\text { Correla- } \\
\text { tion }\end{array}$} & \multicolumn{2}{|c|}{$95 \%$ Confidence Interval } & \multicolumn{3}{c|}{ F Test with True Value 0 } \\
\cline { 3 - 8 } & & $\begin{array}{c}\text { Lower } \\
\text { Bound }\end{array}$ & $\begin{array}{c}\text { Upper } \\
\text { Bound }\end{array}$ & Value & df1 & df2 & Sig. \\
\hline $\begin{array}{c}\text { Preference for } \\
\text { passive experi- } \\
\text { ences }\end{array}$ & 0.600 & 0.547 & 0.647 & 2.667 & 1044 & 4176 & 0.0001 \\
\hline $\begin{array}{c}\text { Preference for } \\
\text { immersive ex- } \\
\text { periences }\end{array}$ & 0.622 & 0.583 & 0.658 & 2.665 & 1044 & 3132 & 0.0001 \\
\hline
\end{tabular}

Source: own research, $\mathrm{N}=1045$ 


\subsection{Hypotheses testing}

The average values of the two scales for the entire sample show that Polish consumers prefer immersive rather than absorbing consumption experiences (the mean for the immersion scale $=3.47$ ) and experiences that do not require active participation (the mean for the passivity scale $=3.57$ ). They prefer 'being' (immersing) in the experience rather than simply observing it from a distance; however, at the same time, they are not interested in active participation in the experience.

Table 6. Differences in the preference for passive/active and immersive/absorbing experiences by demographic characteristics (ANOVA results)

\begin{tabular}{|c|c|c|c|c|c|}
\hline \multicolumn{2}{|l|}{ Variable } & \multicolumn{2}{|c|}{ Preference for passive experiences } & \multicolumn{2}{|c|}{$\begin{array}{l}\text { Preference for immersive experi- } \\
\text { ences }\end{array}$} \\
\hline & & $M$ & SD & $M$ & SD \\
\hline \multirow[t]{2}{*}{ Gender } & female & 3.7011 & 0.9588 & 3.4348 & 1.1171 \\
\hline & male & 3.4287 & 0.9472 & 3.5234 & 1.0901 \\
\hline \multicolumn{2}{|l|}{$\mathrm{F}$} & \multicolumn{2}{|c|}{$21.186^{* *}$} & \multicolumn{2}{|c|}{1.668} \\
\hline \multirow[t]{4}{*}{ Age } & $18-34$ & 3.2598 & 0.9688 & 3.5770 & 1.0099 \\
\hline & $35-49$ & 3.4530 & 0.9314 & 3.3444 & 1.0753 \\
\hline & $50-64$ & 3.7160 & 0.9156 & 3.4626 & 1.2076 \\
\hline & 65 and more & 4.0824 & 0.8053 & 3.4920 & 1.1329 \\
\hline \multicolumn{2}{|l|}{$\mathrm{F}$} & \multicolumn{2}{|c|}{$35.603^{* *}$} & \multicolumn{2}{|c|}{2.124} \\
\hline \multirow{2}{*}{$\begin{array}{l}\text { Household } \\
\text { income per } \\
\text { capita }\end{array}$} & $\leq 1,000 \mathrm{PLN}$ & 3.6544 & 0.9511 & 3.4782 & 1.1027 \\
\hline & $>1,000 \mathrm{PLN}$ & 3.4841 & 0.9688 & 3.4726 & 1.1091 \\
\hline \multicolumn{2}{|l|}{$\mathrm{F}$} & \multicolumn{2}{|c|}{$7.541^{*}$} & \multicolumn{2}{|c|}{0.007} \\
\hline \multirow{4}{*}{$\begin{array}{l}\text { Size of } \\
\text { population of } \\
\text { the place of } \\
\text { residence }\end{array}$} & $\begin{array}{l}\text { up to } 10,000 \\
\text { inhabitants }\end{array}$ & 3.6006 & 0.9461 & 3.3579 & 1.1039 \\
\hline & $\begin{array}{l}10,000 \text { to } 99,999 \\
\text { inhabitants }\end{array}$ & 3.5367 & 0.9733 & 3.5186 & 1.1259 \\
\hline & $\begin{array}{l}100,000 \text { to } \\
499,999 \text { inhabi- } \\
\text { tants }\end{array}$ & 3.6852 & 0.9524 & 3.5044 & 1.0806 \\
\hline & $\begin{array}{l}\text { above } 500,000 \\
\text { inhabitants }\end{array}$ & 3.4529 & 0.9885 & 3.6925 & 1.0164 \\
\hline \multicolumn{2}{|l|}{$\mathrm{F}$} & \multicolumn{2}{|c|}{1.518} & \multicolumn{2}{|c|}{$\frac{1}{2.743^{*}}$} \\
\hline
\end{tabular}

Source: own research, $\mathrm{N}=1045$

${ }^{*} p=0.05 .{ }^{* *} p=0.001$, where 1 indicates "strongly disagree" and 5 "strongly agree".

The one-way analysis of variance (ANOVA) was performed to test the research hypotheses stated above (see Table 6). Levene's test for homogeneity of variances was conducted for each variable and was insignificant at a level of 0.05. Regarding gender, women are more likely to choose passive experiences than men, but no difference in the preference towards immersive experiences was found between men and women. These results support hypothesis $\mathrm{H} 1 \mathrm{a}$ and reject $\mathrm{H} 1 \mathrm{~b}$. The youngest age group has the lowest preference for passive involve- 
ment in consumption experiences, and the preference for passive involvement increases with respondent age. However, no relationship between age and preference towards immersive experiences was found. Thus, hypothesis $\mathrm{H} 2 \mathrm{a}$ was positively verified, but not $\mathrm{H} 2 \mathrm{~b}$. Respondents with income above the national average are less willing to participate in passive experiences, yet the tendency to choose immersion does not depend on income level. Hence, hypothesis H3 a was supported, and $\mathrm{H} 3 \mathrm{~b}$ was rejected. In the case of the place of residence, we found no differences in the preference for passive experiences, leaving the hypothesis $\mathrm{H} 4$ a unsupported. However, there is a significant relationship between the place of residence and the desired immersion level such that residents of major cities have a higher inclination to choose immersive experiences than those living in rural areas and small towns. Therefore, hypothesis $\mathrm{H} 4 \mathrm{~b}$ was empirically confirmed.

\subsection{Cluster analysis}

In the last step, the cluster analysis was used to group consumers into segments based on their results on the passive/active and immersive/absorbing scales. This analysis also allowed us to verify whether demographic characteristics differ between the identified groups, thus providing a more in-depth understanding of the findings presented above. Accordingly, the results of the cluster analysis showed that the largest group of respondents was classified as preferring esthetic experiences $(38.3 \%)$, with escapist experiences $(25.6 \%)$ in second place. Both of these experience realms indicate a preference for immersion - passive immersion for esthetic consumption experiences and active immersion for escapist consumption experiences. Fewer respondents were classified in the educational $(19.7 \%)$ and entertainment (16.4\%) segments, which are connected with active and passive absorption, respectively (see Table 7).

As seen in Table 7, the variables such as gender, age and income are linked with segment membership in a statistically significant way. However, no relationship between the place of residence and segment membership was observed. When we look at the demographic characteristics of the segments, we see that women predominate among enthusiasts of entertainment (62.7\%) and esthetic (57.7\%) consumption experiences (passive realms), and men predominate in the segments of educational $(52.7 \%)$ and escapist $(53.7 \%)$ experiences (active realms). Similarly, when income is concerned, poorer consumers are more likely to be categorized in the entertainment and esthetics segments and richer consumers are more likely to be categorized in the educational and escapist segments. In regard to age, almost half of those belonging to the escapist segment (active and immersive experience) are the youngest respondents (18-34 years). Consumers under 50 years of age constitute $67.1 \%$ of those classified in the educational segment. Respondents aged 50-64 are the largest group within the esthetic 
(31.1\%) and entertainment (30.3\%) cluster (passive realms), in which the oldest age group (over 64 years) is more represented than the groups aged 18-34 and $35-49$.

Table 7. Segment membership according to demographic variables

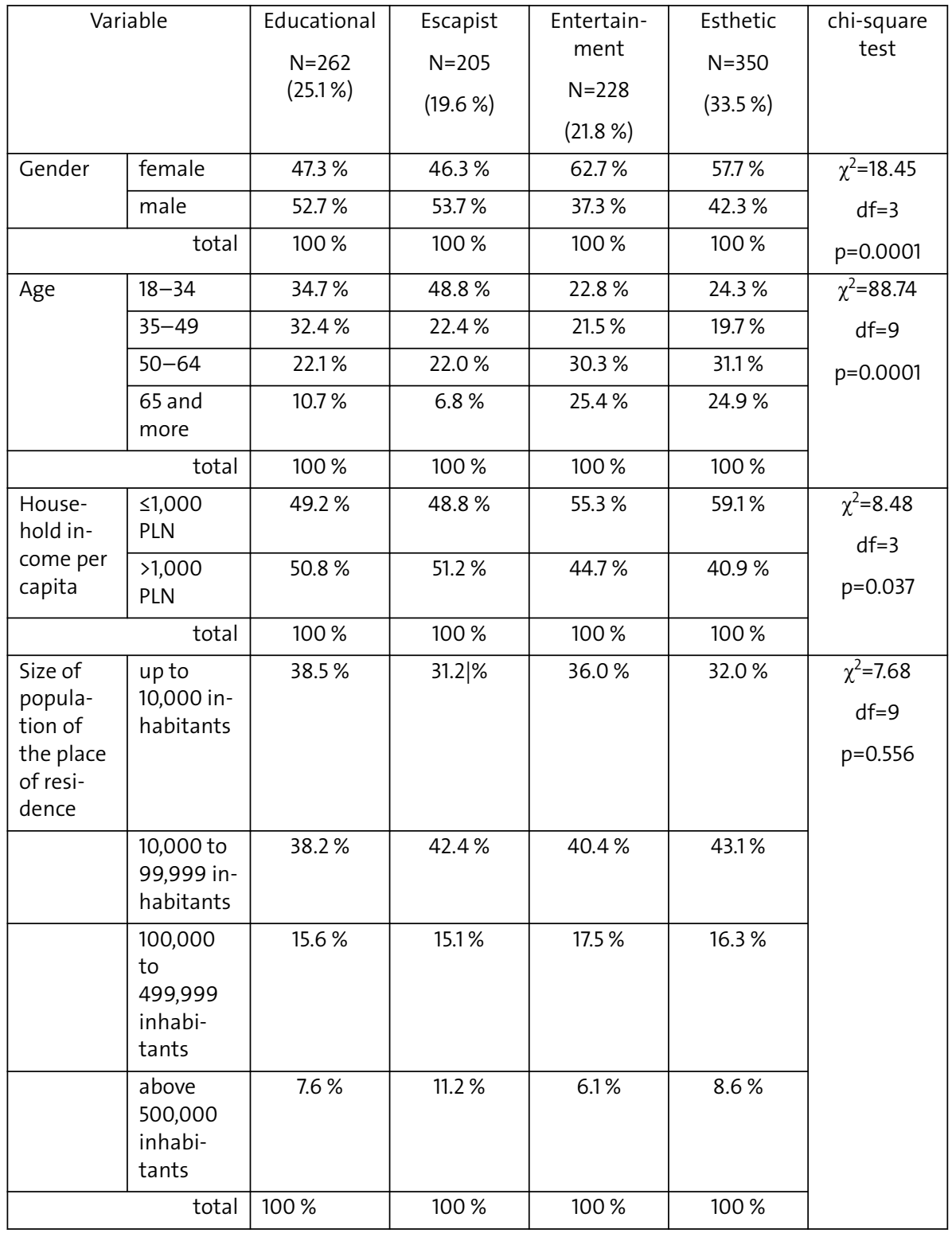

Source: own research, $\mathrm{N}=1045$ 
Figure 2. Segment membership and hedonic shopping motivations
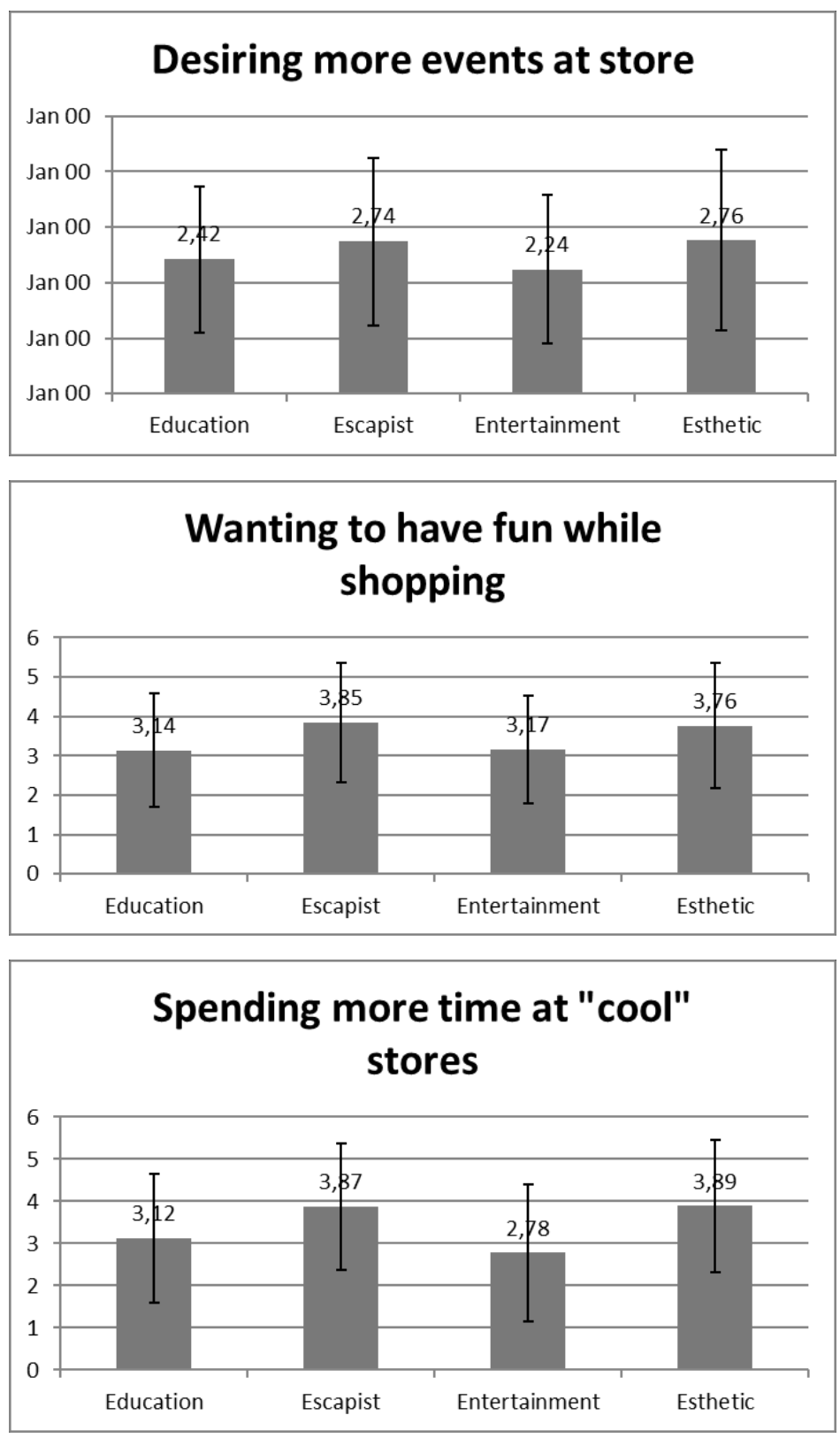

*mean values and standard deviations for each segment (5-point Likert scale) Source: own research, $\mathrm{N}=1045$ 
Finally, to support the relation between segments based on general consumers' preferences for passive or immersive consumption experiences, the analysis of variance and a post hoc Tukey test were conducted with the use of three additional variables directly connected to a shopping context. This approach allows further evaluation of the proposed cluster's solution and indicates that proposed segmentation can be applied in practice. The three questions used for this purpose were as follows: "I think shopping should also be fun", "I wish more events were happening in stores" and "I spend more time in stores that are cool". The results of the analysis of variance showed a statistically significant difference between the segments. The post hoc Tukey test verified which mean values differed significantly among the segments. As presented in Figure 2, wanting to have fun while shopping is more common among the members of the escapist and esthetic segments than those of the entertainment and educational segments. Thus, this variable is linked to seeking an immersive experience. The representatives of the escapist and the esthetic segments show a more positive attitude towards events occurring in stores and spend more time in stores that are perceived as "cool" than representatives of the remaining two segments.

\section{Discussion}

The results presented above show that consumers have different preferences in terms of the level of activeness/passiveness and immersion/absorption of consumption experiences, which are linked with their demographic characteristics and attitudes towards a shopping situation. This opens the discussion about the applicability of Pine and Gilmore's concept of the 'sweet spot' claiming that the richest experiences need to encompass all four realms. In fact, it seems that although all realms of the consumption experience should be addressed by marketers, they should not be treated as equally important, and consumer preferences should be seriously considered.

The favourite experience realm of Polish consumers appears to be the esthetic realm, which is consistent with studies by Oh et al. (2007), Jeong et al. (2009), Pikkemaat et al. (2009), Hosany and Witham (2010), and Manthiou et al. (2014). Therefore, we can assume that this preference of Polish consumers may be a global tendency rather than a cultural trait. On the other hand, the least preferred experience realm seems to be the escapist realm.

The relationship between the preferred type of experience and variables such as age, gender and income of the respondent was found to be statistically significant in the case of preferences for passive/active experiences, while the place of residence was found to be statistically significant in the case of preferences for immersive/absorbing experiences.

Younger respondents most often choose escapist experiences, which can be explained by the fact that members of Generation $\mathrm{Y}$ think of themselves as part of 
a group known as "Netizens", namely, people whose main means of communication is the Internet (Tapscott 2008). This medium provides opportunities for immersion at a high level and requires active participation from its users. Traditional media such as radio, newspapers and television provide more passive experiences, which can explain the greater popularity of esthetic or entertainment experiences among older age groups. Another factor contributing to such a distribution of preferences may be that escapist and educational aspects of consumption experiences (especially in a shopping context) are a fairly new phenomenon, and younger consumers tend to be more open to such novelties than older consumers. Because Poland is a post-transitional economy and a postcommunist country, it is worth noting that the older generation of consumers seeks more materialistic values than the younger generation, which in turn is more eager to look for immaterial experiences (Inglehart 1997, Czapiński/Panek 2015).

According to the results of our study, women are more willing than men to take part in experiences that involve passive participation (i.e., entertainment and esthetic). This willingness may stem from the fact that Polish society is fairly traditional, and during the process of socialization, boys are encouraged to be more active (Röder/Mühlau 2014). The lower likelihood of poorer consumers to choose active experiences (educational, escapist) may result from their inability to pay higher prices for a truly unique and engaging consumption experience. This result is in line with the latest research of Tully et al. (2015), who determined that consumers with constrained financial resources tend to choose material goods rather than experiences. Additionally, in the Polish context, elderly people are to some extent excluded from consumption activities due to their poor financial situation after retirement, and the results of our study clearly show a much lower preference for escapist and educational experiences among people aged 64 and older. Finally, the tendency of residents of large cities to prefer more immersive experiences may stem from the fact that this type of consumption experience is easier to access in larger cities.

\section{Conclusions}

The presented research contributes to the discussion on understanding the consumer experience, its components and its dimensions. It provides a measurement scale that can be applied not only in the primary sector of the experience economy (i.e., leisure activities such as tourism) but also to the general consumption context (the secondary sector of the experience economy) (Sundbo/Sorensen 2013). Our study shows that consumers seek different types of experiences, and a perfect consumption situation may focus on only one or two experience realms rather than all of them, which is in line with Oh et al. (2007) and Jeong et al.'s (2009) findings. The paper also demonstrates that certain characteristics, such as 
gender, age and income level, make some consumers more attracted to a particular type of experience.

Although the two largest segments of Polish consumers opted for passive and immersive experiences, treating consumption experiences in a rather utilitarian manner, they still reported high satisfaction with their course. This finding shows that consumers have their own ideas as to what the optimal experience is, and they do not want to be forced to act it in a pre-designed way. What seems to be important to consumers is the possibility of choosing their own way of doing things with the support from the company (its products and services). Therefore, it can be concluded that even though they are less interested in active participation, they still want to co-create their experiences on their own terms (Boswijk et al. 2007).

As far as managerial implications are concerned, our research suggests that companies should exercise caution when implementing tools and techniques of the experience economy. Despite Pine and Gilmore's $(1999,2011)$ enthusiastic point of view, clearly, not all consumers are equally ready to plunge into the experience, especially for experiences occurring in the secondary sector of the experience economy and that are not purely for the purpose of leisure. Shopping experiences can be both a pleasurable pastime and a tiresome obligation. Therefore, it cannot be expected that consumers with different demographic characteristics that influence their shopping agendas and attitudes will equally enjoy the same things.

Engaging consumers 'by force' in all realms of the consumption experience in the name of achieving the 'sweet spot' when consumers do not want to participate in some of the realms can be counterproductive. This observation is in line with the data presented by Meyer and Schwager (2007), who reported that $80 \%$ o $\%$ the studied companies believed that the experience they provided was superior, while only $8 \%$ o \% the consumers shared that opinion. It seems that the best solution is to provide consumers with a set of options and to allow them to decide what they do and how they do it. Prahalad and Ramaswamy (2004) describe such a solution in the form of platforms of goods and services that allow for true co-creation of experiences. For example, the presence of both self-serve and full-serve checkouts in a store, both a buffet and menu a la carte in a restaurant, and augmented reality fitting rooms in an online store and high-quality pictures of offered merchandise allow the consumer to choose the most suitable type of experience in a given situation. It can be expected that consumers who are in control of their experiences (i.e. decide about their level of involvement) will eventually be more satisfied with the outcome.

The study presented in this paper is not without limitations. First, it should be noted that the participants in our study were from Poland, and it is an open question whether the revealed reluctance to active participation in consumption 
experiences presented by women, the elderly and the poor is culture-specific or whether similar results can be obtained in other countries. In particular, it would be informative to compare societies with different levels of economic development. Further research may also include an analysis of how the preference for certain experience realms relates to psychographic variables such as the temperament or personality of the consumer.

Second, the data gathered is of a declarative nature, and although it clearly provides us with a substantial amount of information on what consumers say they do, it does not inform us about consumers' actual behaviours. Therefore, it is suggested that other research methods, such as observations and experiments, be applied to achieve a deeper understanding of consumption experience.

Finally, the verified measurement scale used in the study is developed in a way that explicitly captures only two dimensions of the consumption experience (i. e., passivity and immersion). Although it is implied that low scores in the passivity dimension signify the preference towards more active experiences and that low scores in the immersion dimension signify the preference towards absorption, it is still suggested that further research be conducted to develop a more precise scale.

\section{Acknowledgments}

This article was based on research conducted as part of a project funded by Narodowe Centrum Nauki (National Science Centre): decision number DEC-2012/05/B/HS4/04213.

\section{References}

Abrahams, R. (1986) Ordinary and Extraordinary experiences, in Turner, V.W. \& Bruner, E.M. (eds.): The Anthropology of Experince. Urbana: University of Illinois Press, 45-73.

Aho, S. K. (2001): Towards a general Theory of touristic Experiences: Modelling Experience Process in Tourism, in: Tourism Review, 56, 3/4,33-37.

Allard, T./Babin, B. J./Chebat, J.-C. (2009): When income matters: Customers evaluation of shopping malls' hedonic and utilitarian orientations, in: Journal of Retailing and Consumer Services, $16,1,40-49$.

Arnould, E. J./Price, L. L. (1993): River magic: Extraordinary experience and the extended service encounter, in: Journal of Consumer Research, 20, 1,24-45.

Atwal, G./Williams, A. (2009): Luxury brand marketing - The experience is everything!, in: Journal of Brand Management, 16, 5-6,338-346.

Bakewell, C./Mitchell, V. (2003): Generation Y female consumer decision-making, in: International Journal of Retail and Distribution Management, 31, 2/3,95-106.

Boswijk, A./Thijssen, T./Peelen, E. (2007): The experience economy - a new perspective. Amsterdam: Prentice Hall Pearson. 
Brakus, J./Schmitt, B./Zarantonello, L. (2009): Brand Experience: What is It? How do We Measure It? And Does It Affect Loyalty?, in: Journal of Marketing, 73, 3,52-68.

Carpenter, J. M. (2008): Demographics and patronage motives of supercenter shoppers in the United States, in: International Journal of Retail and Distribution Management, 36, 1,5-16.

Caru, A./Cova, B. (2003): Revisiting Consumption Experience. A More Humble but Complete View of the Concept, in: Marketing Theory, 3, 2,267-286.

Chang, E./Burns, L. D./Francis, S. K. (2004): Gender differences in the dimensional structure of apparel shopping satisfaction among Korean consumers: The role of hedonic shopping value, in: Clothing and Textiles Research Journal, 22, 4,185-199.

Choi, E./Ko, E./Kim, A. J. (2016): Explaining and predicting purchase intentions following luxury-fashion brand value co-creation encounters, in: Journal of Business Research, 69, $12,5827-5832$.

Christensen, B. A. (2013): Connecting Experience and Economy - Aspects of Disguised Positioning, in: Integrative Psychological \& Behavioral Science, 47, 1,77-94.

Churchill, G. (1979): A Paradigm for Developing Better Measures of Marketing Constructs, in: Journal of Marketing Research, 16, 1,64-73.

Churchill, G./Peter, P. (1984): Research Design Effects on the Reliability of Rating Scales: A Meta-Analysis, in: Journal of Marketing Research, 21, 4,360-375.

Czapiński, J./Panek, T. (2015) Diagnoza społeczna. Warunki i jakość życia Polaków., Warszawa: Rada Monitoringu Społecznego.

Davis, R./Lang, B./San Diego, J. (2014): How gender affects the relationship between hedonic shopping motivation and purchase intentions?, in: Journal of Consumer Behaviour, 13, $1,18-30$.

Deshwal, P. (2016): Customer experience quality and demographic variables (age, gender, education level, and family income) in retail stores, in: International Journal of Retail and Distribution Management, 44, 9,940-955.

Dewey, J. (1925): Experience and Nature. New York: Dover.

Diamantopoulos, A./Schlegelmilch, B. B./Sinkovics, R. R./Bohlen, G. M. (2003): Can sociodemographics still play a role in profiling green consumers? A review of the evidence and an empirical investigation, in: Journal of Business Research, 56, 6,465-480.

Eastman, J. K./Iyer, R./Thomas, S. P. (2013): The impact of status consumption on shoppinstyles: an exploratory look at the millennial generation, in: Marketing Management Journal, 23, 1,57-73.

Ferreira, H./Teixeira, A. (2013): 'Welcome to the experience economy': assessing the influence of customer experience literature through bibliometric analysis, in: Working Papers (FEP) -- Universidade do Porto, 481,1-28.

Firat, A./Dholakia, N. (1998): Consuming People: From Political Economy to Theaters of Consumption. London: Sage.

Fulgsang, L./Sundbo, J./Sorensen, F. (2011): Dynamics of experience service innovation: innovation as a guided activity - results from a Danish survey, in: The Service Industries Journal, 31, 5,661-677.

Garðarsdóttir, R. B./Dittmar, H. (2012): The relationship of materialism to debt and financial well-being: The case of Iceland's perceived prosperity, in: Journal of Economic Psychology, $33,3,471-481$. 
Gentile, C./Spiller, N./Noci, G. (2007): How to sustain the customer experience: An overview of experience components that co-create value with the customer, in: European Management Journal, 25, 5,395-410.

Gram, M. (2011): Approaching children in experience advertising : Danish amusement parks 1969-2008, in: Young consumers : insight and ideas for responsible marketers, 12, 1,5365.

Hair, J. F./Black, W. C./Babin, B. J./Anderson, R. E. (2014): Multivariate Data Analysis: Pearson New International Edition. Harlow, Essex: Pearson.

Hamilton, K. (2012): Low-income Families and Coping through Brands: Inclusion or Stigma?, in: Sociology, 46, 1,74-90.

Hart, C./Farrell, A. M./Stachow, G./Reed, G./Cadogan, J. W. (2007): Enjoyment of the Shopping Experience - Impact on customers' repatronage intentions and gender influence, in: The Service Industries Journal, 27, 5,583-604.

Heinonen, K./Strandvik, T./Voima, P. (2013): Customer dominant value formation in service, in: $25,2,104-123$.

Holbrook, M./Hirschman, E. (1982): The Experiential Aspects of Consumption: Consumer Fantasy, Feelings and Fun, in: Journal of Consumer Research, 9, 2,132-140.

Hosany, S./Witham, M. (2010): Dimensions of cruisers' experiences, satisfaction, and intention to recommend, in: Journal of Travel Research, 49, 3,351-364.

Inglehart, R. (1997): Modernization and Postmodernization: Cultural, Economic and Political Change in 43 Societies. Princeton: Princeton University Press.

Ishida, C./Taylor, S. A. (2012): Retailer Brand Experience, Brand Experience Congruence, and Consumer Satisfaction, in: Journal of Consumer Satisfaction, Dissatisfaction and Complaining Behavior, 25, 1,63-78.

Iyanna, S./Bosangit, C./Mohd-Any, A. A. (2012): Value evaluation of customer exprience using consumer generated content, in: International Journal of Management and Marketing Research, 5, 2,89-102.

Jackson, V./Stoel, L./Brantley, A. (2011): Mall attributes and shopping value: Differences by gender and generational cohort, in: Journal of Retailing and Consumer Services, 18, 1,1-9.

Japutra, A./Molinillo, S. (2018): Responsible and active brand personality: On the relationships with brand experience and key relationship constructs, in: Journal of Business Research, 44,In press.

Jeong, S. W./Fiore, A. M./Niehm, L. S./Lorenz, F. O. (2009): The role of experiential value in online shopping: The impacts of product presentation on consumer responses towards an apparel web site, in: Internet Research, 19, 1,105-124.

Johanson, G. A./Brooks, G. P. (2010): Initial Scale Development: Sample Size for Pilot Studies, in: Educational and Psychological Measurement, 70, 3,394-400.

Jones Lang LaSalle (2017) Rynek handlowy w Polsce. Available at: http://www.jll.pl/poland/p l-pl/raporty/wiadomosci?k=rynek\%20handlowy.

Jurkowski, C. 'An Examination of the Four Realms of Tourism Experience Theory', International CHRIE Conference-Refereed Track: University of Massachusetts - Amherst.

Keng, C.-J./Tran, V.-D./Liao, T.-H./Yao, C.-J./Hsu, M. K. (2014): Sequential combination of consumer experiences and their impact on product knowledge and brand attitudeThe moderating role of desire for unique consumer products, in: Internet Research, 24, 3,270-291. 
Kotler, P./Kartajaya, H./Setiawan, I. (2017): Marketing 4.0 : Moving From Traditional to Digital. Hoboken, New Jersey: Wiley.

Krot, K./Glińska, E. (2014): Economic exclusion of older consumers in Poland in the context of consumer culture theory / Ekonomiczne wykluczenie seniorów w Polsce w kontekście teorii kultury konsumpcji, in: Ekonomia i Zarządzanie / Economics and Management, $1,57-78$.

Leung, A./Huimin, X./Schocker, J. (2013): Staging the Museumspace: Overlapping Personal, Social, and Hedonic Experiences, in: Advances in Consumer Research, 41,582-582.

Lo, A./Qu, H./Wetprasit, P. (2013): Realms of Tourism Spa Experience: The Case of Mainland Chinese Tourists, in: Journal of China Tourism Research, 9, 4,429-451.

Mahmoud, R. R. A./Bagozzi, R. P./Kortam, W. A./Mahrous, A. A. (2016): The journey from consumers to co-creators: exploring consumers' co-creation experiences by means of neurophysiological tools, in: Proceedings of the Marketing Management Association,157-158.

Maklan, S./Klaus, P. (2011): Customer experiences. Are we measuring the right things?, in: International Journal of Market Research, 53, 6,771-792.

Manthiou, A./Lee, S./Tang, L. R./Chiang, L. (2014): The experience economy approach to festival marketing: Vivid memory and attendee loyalty, in: Journal of Services Marketing, $28,1,22-35$.

McDonald, M./Dunbar, I. 2012. Market Segmentation : How to Do It and How to Profit from It. Chichester: Wiley.

Meyer, C./Schwager, A. (2007): Understanding Customer Experience, in: Harvard Business Review, 85, 2,116-126.

Myers, J. H. 1996. Segmentation and positioning for strategic marketing decisions. Chicago: American Marketing Association.

Nijboer, J. (2006): Cultural entrepreneurship in libraries, in: New Library World, 107, 9/10,434-443.

Nunnally, J. C. (1978): Psychometric theory. McGraw-Hill Series in Psychology. New York: McGraw-Hill.

Nysveen, H./Pedersen, P. E. (2014): Influences of co-creation on brand experience, in: International Journal of Market Research, 56, 6,807-832.

O'Sullivan, E./Spangler, K. (1998): Experience Marketing: Strategies for the new millennium. State College: Venture Publishing.

Oh, H./Fiore, A. M./Jeoung, M. (2007): Measuring Experience Economy Concepts: Tourism Applications, in: Journal of Travel Research, 46, 2,119-132.

Otto, J. E./Ritchie, J. B. (1996): The service experience in tourism, in: Tourism Management, 17, 3,165-174.

Patel, J. D./Bhatt, N./Shukla, Y./Gadhavi, D. (2015): Antecedents of rural and urban consumers' propensity to outshop and product specific outshopping behaviour, in: Journal of Retailing and Consumer Services, 26,97-103.

Pedrini, M./Ferri, L. M. (2014): Socio-demographical antecedents of responsible consumerism propensity, in: International Journal of Consumer Studies, 38, 2,127-138.

Petermans, A./Janssens, W./Van Cleempoel, K. (2013): A Holistic Framework for Conceptualizing Customer Experiences in Retail Environments, in: International Journal of Design, $7,2,1-18$. 
Pikkemaat, B./Peters, M./Boksberger, P./Secco, M. (2009): The Staging of Experiences in

Wine Tourism, in: Journal of Hospitality Marketing \& Management, 18, 2/3,237-253.

Pine, J./Gilmore, J. (1999): The Experience Economy: Work is Theatre \& Every Business a Stage. Boston: Harvard Business School Press.

Pine, J./Gilmore, J. (2011): The Experience Economy. Boston: Harvard Business Review Press.

Pinker, S. (1997): How the Mind Works. New York: Norton.

Prahalad, C. K./Ramaswamy, V. (2004): Co-creation experiences: The next practice in value creation, in: Journal of Interactive Marketing, 18, 3,5-14.

Pullman, M./Gross, M. (2004): Ability of experience design elements to elicit emotions and loyalty behaviors, in: Decision Sciences, 35, 3,551-578.

Punj, G. (2012): Income effects on relative importance of two online purchase goals: Saving time versus saving money?, in: Journal of Business Research, 65, 5,634-640.

Quadri-Felitti, D./Fiore, A. M. (2012): Experience economy constructs as a framework for understanding wine tourism, in: Journal of Vacation Marketing, 18, 1,3-15.

Röder, A./Mühlau, P. (2014): Are They Acculturating? Europe's Immigrants and Gender Egalitarianism, in: Social Forces, 92, 3,899-928.

Schewe, C. D./Noble, S. M. (2000): Market Segmentation by Cohorts: The Value and Validity of Cohorts in America and Abroad, in: Journal of Marketing Management, 16, 1-3,129142.

Schmitt, B. (1999): Experiential Marketing: How to Get Customers to Sense, Feel, Think, Act, and Relate to Your Company and Brands. New York: Free Press.

Seo, Y. (2013): Electronic sports: A new marketing landscape of the experience economy, in: Journal of Marketing Management, 29, 13-14,1542-1560.

Sheng, M. L./Teo, T. S. H. (2012): Product attributes and brand equity in the mobile domain: The mediating role of customer experience, in: International Journal of Information Management, 32,139-146.

Shrout, P. E./Fleiss, J. L. (1979): Intraclass correlations: Uses in assessing rater reliability, in: Psychological Bulletin, 86, 2,420-428.

Shukla, P./Banerjee, M./Adidam, P. T. (2013): The moderating influence of socio-demographic factors on the relationship between consumer psychographics and the attitude towards private label brands, in: Journal of Consumer Behaviour, 12, 6,423-435.

Smidt-Jensen, S./Skytt, C. B./Winther, L. (2009): The Geography of the Experience Economy in Denmark: Employment Change and Location Dynamics in Attendance-based Experience Industries, in: European Planning Studies, 17, 6,847-862.

Solomon, M. (2013): Consumer Behavior. Buying, having and being. Edinburgh Gate: Pearson Education Limited.

Sundbo, J./Bærenholdt, J. (2007) Indledning: Den mangfoldige oplevelsesøkonomi, in Sundbo, J. \& Bærenholdt, J. (eds.): Oplevelsesøkonomi: Produktion forbrug kultur. Copenhagen: Samfundslitteratur.

Sundbo, J./Sorensen, F. (2013): Handbook on Experience Economy. Cheltenham: Edward Elgar Publishing Limited.

Tabachnick, B. G./Fidell, L. S. (2007): Using multivariate statistics. Boston: Pearson/Allyn \& Bacon. 
Tapscott, D. (2008): Grown Up Digital: How the Net Generation is Changing Your World. New York: McGraw- Hill.

Tully, S. M./Hershfield, H. E./Meyvis, T. (2015): Seeking lasting enjoyment with limited money: Financial constraints increase preference for material goods over experiences, in: Journal of Consumer Research, 42, 1,59-75.

Vargo, S./Lusch, R. (2008): Service-dominant logic: continuing the evolution, in: Journal of the Academy of Marketing Science, 47, 1,1-10.

Verhoef, P. C./Lemon, K. N./Parasuraman, A./Roggeveen, A./Tsiros, M./Schlesinger, L. A. (2009): Customer Experience Creation: Determinants, Dynamics and Management Strategies, in: Journal of Retailing, 85, 1,31-41.

Verleye, K. (2015): The co-creation experience from the customer perspective : its measurement and determinants, in: Journal of Service Management, 26, 2,321-342.

Wedel, M./Kamakura, W. (2003): Market segmentation. Conceptual and Methodological Foundations. Boston: Kluwer Academic Publishers.

Zarantonello, L./Schmitt, B. (2010): Using the brand experience scale to profile consumers and predict consumer behaviour, in: Brand Management, 17, 7,532-540.

Zhang, H./Lu, Y./Wang, B./Wu, S. (2015): The impacts of technological environments and cocreation experiences on customer participation, in: Information \& Management, 52, 4,468482.

Zhao, N./Dong, Q. (2013): Quantitative Research of Consumer Experience Types Based on Online Reviews: With the Example of Automotive Products, in: Information Technology Journal, 12, 20,5865-5868.

\section{APPENDIX}

\section{Table A. The initial list of survey items.}

\begin{tabular}{|l|l|}
\hline \multicolumn{2}{|l|}{ PREFERENCE FOR PASSIVE EXPERIENCES } \\
\hline 1. & I prefer to watch from a distance than to take part directly in games and contests. \\
\hline 2. & $\begin{array}{l}\text { In my free time, I like to clear my mind by listening to music, watching TV or reading } \\
\text { books.* }^{* *}\end{array}$ \\
\hline 3. & $\begin{array}{l}\text { Observing other people's participation in organized pastimes gives me more pleasure } \\
\text { than participating in them myself. }\end{array}$ \\
\hline 4. & $\begin{array}{l}\text { I dislike it when someone tries to persuade me to actively engage in some kind of enter- } \\
\text { tainment. }\end{array}$ \\
\hline 5. & I mostly like to spend free time relaxing in the comfort of my own home. \\
\hline 6. & I choose such forms of entertainment that do not require too much activity from me. \\
\hline 7. & I am happy to participate in various new types of classes related to physical activity. \\
\hline 8. & I like to take part in organized classes or courses that require my active participation. ${ }^{* *}$ \\
\hline 9. & Physical activity is very important to me. ${ }^{*}$ \\
\hline 10. & I like leading a very active lifestyle. ${ }^{* *}$ \\
\hline 11. & Passive forms of entertainment are not for me. \\
\hline
\end{tabular}




\begin{tabular}{|c|c|}
\hline \multicolumn{2}{|c|}{ PREFERENCE FOR IMMERSIVE EXPERIENCES } \\
\hline 12. & $\begin{array}{l}\text { I most enjoy forms of entertainment that allow me to forget about the rest of the } \\
\text { world.**** }\end{array}$ \\
\hline 13. & I like activities that require creativity from me.* \\
\hline 14. & $\begin{array}{l}\text { I prefer forms of entertainment that require active participation and allow me to decide } \\
\text { on their course. }\end{array}$ \\
\hline 15. & I often get involved in activities, during which I forget about the passage of time.**** \\
\hline 16. & I prefer to play games than watch movies.** \\
\hline 17. & I have a hobby that completely consumes my time and attention. \\
\hline 18. & $\begin{array}{l}\text { I like to experience exceptional things, created especially for me, that nobody else has ex- } \\
\text { perienced.** }\end{array}$ \\
\hline 19. & During entertainment, I like to feel like someone extraordinary.** \\
\hline 20. & I do not need entertainment that would take me away from reality.*** \\
\hline 21. & $\begin{array}{l}\text { While admiring nature, interiors and objects, I can completely forget about the passage } \\
\text { of time. }{ }^{* * * *}\end{array}$ \\
\hline 22. & I easily get bored.* \\
\hline 23. & I strive to make my life full of exciting events. ${ }^{*}$ \\
\hline 24. & I don't like to lose control over the passage of time.*** \\
\hline 25. & I prefer to watch what is happening around me rather than become engaged.** \\
\hline
\end{tabular}

* removed after consultations with experts due to potentially low face and content validity

** removed after the first pilot study on the sample of 100 management students due to low factor loadings and possible Cronbach's alpha improvement if deleted.

*** removed after the second pilot study on the sample of 100 management students

**** rephrased after the experts' and pilot study participants' remarks

Table B. Exploratory factor analysis results $-\mathrm{KMO}$ and Bartlett's test

\begin{tabular}{|l|l|r|}
\hline \multicolumn{2}{|c|}{} \\
\hline Kaiser-Meyer-Olkin Measure of Sampling Adequacy. & 0,682 \\
\hline Bartlett's Test of Sphericity & Chi-Square & 1137,112 \\
\cline { 2 - 3 } & $\mathrm{df}$ & 36 \\
\cline { 2 - 3 } & $\mathrm{p}$ & 0,0001 \\
\hline
\end{tabular}

Source: own research, $\mathrm{N}=1045$ 
Table C. Exploratory factor analysis results - total variance explained

\begin{tabular}{|c|c|c|c|c|c|c|c|c|c|}
\hline \multirow[b]{2}{*}{$\begin{array}{l}\text { Com- } \\
\text { ponent }\end{array}$} & \multicolumn{3}{|c|}{$\begin{array}{c}\text { Initial } \\
\text { Eigenvalues }\end{array}$} & \multicolumn{3}{|c|}{$\begin{array}{l}\text { Extraction Sums } \\
\text { of Squared Loadings }\end{array}$} & \multicolumn{3}{|c|}{$\begin{array}{c}\text { Rotation Sums } \\
\text { of Squared Loadings }\end{array}$} \\
\hline & Total & $\begin{array}{l}\text { \% of } \\
\text { Vari- } \\
\text { ance }\end{array}$ & $\begin{array}{c}\text { Cumu- } \\
\text { lative } \\
\%\end{array}$ & Total & $\begin{array}{l}\text { \% of } \\
\text { Vari- } \\
\text { ance }\end{array}$ & $\begin{array}{c}\text { Cumu- } \\
\text { lative } \\
\%\end{array}$ & Total & $\begin{array}{l}\text { \% of } \\
\text { Vari- } \\
\text { ance }\end{array}$ & $\begin{array}{c}\text { Cumu- } \\
\text { lative } \\
\%\end{array}$ \\
\hline 1 & 2.100 & 23.332 & 23.332 & 2.100 & 23.332 & 23.332 & 2.029 & 22.542 & 22.542 \\
\hline 2 & 1.844 & 20.494 & 43.827 & 1.844 & 20.494 & 43.827 & 1.916 & 21.285 & 43.827 \\
\hline 3 & 0.930 & 10.334 & 54.161 & & & & & & \\
\hline 4 & 0.881 & 9.787 & 63.948 & & & & & & \\
\hline 5 & 0.809 & 8.988 & 72.936 & & & & & & \\
\hline 6 & 0.716 & 7.955 & 80.891 & & & & & & \\
\hline 7 & 0.675 & 7.504 & 88.395 & & & & & & \\
\hline 8 & 0.574 & 6.378 & 94.773 & & & & & & \\
\hline 9 & 0.470 & 5.227 & 100.000 & & & & & & \\
\hline
\end{tabular}

Source: own research, $\mathrm{N}=1045$

Table D. Exploratory factor analysis results - rotated components matrix

\begin{tabular}{|c|c|c|}
\hline \multirow{2}{*}{ Item } & \multicolumn{2}{|c|}{ Component } \\
\cline { 2 - 3 } & 1 & 2 \\
\hline P4 & 0.723 & 0.001 \\
\hline P5 & 0.703 & 0.055 \\
\hline P3 & 0.615 & -0.053 \\
\hline P1 & 0.552 & -0.027 \\
\hline P2 & 0.546 & -0.018 \\
\hline P9 & -0.123 & 0.815 \\
\hline P7 & -0.094 & 0.718 \\
\hline P6 & 0.041 & 0.660 \\
\hline P8 & 0.079 & 0.542 \\
\hline
\end{tabular}

Source: own research, $\mathrm{N}=1045$ 
Figure 3. Confirmatory factor analysis results - measurement model

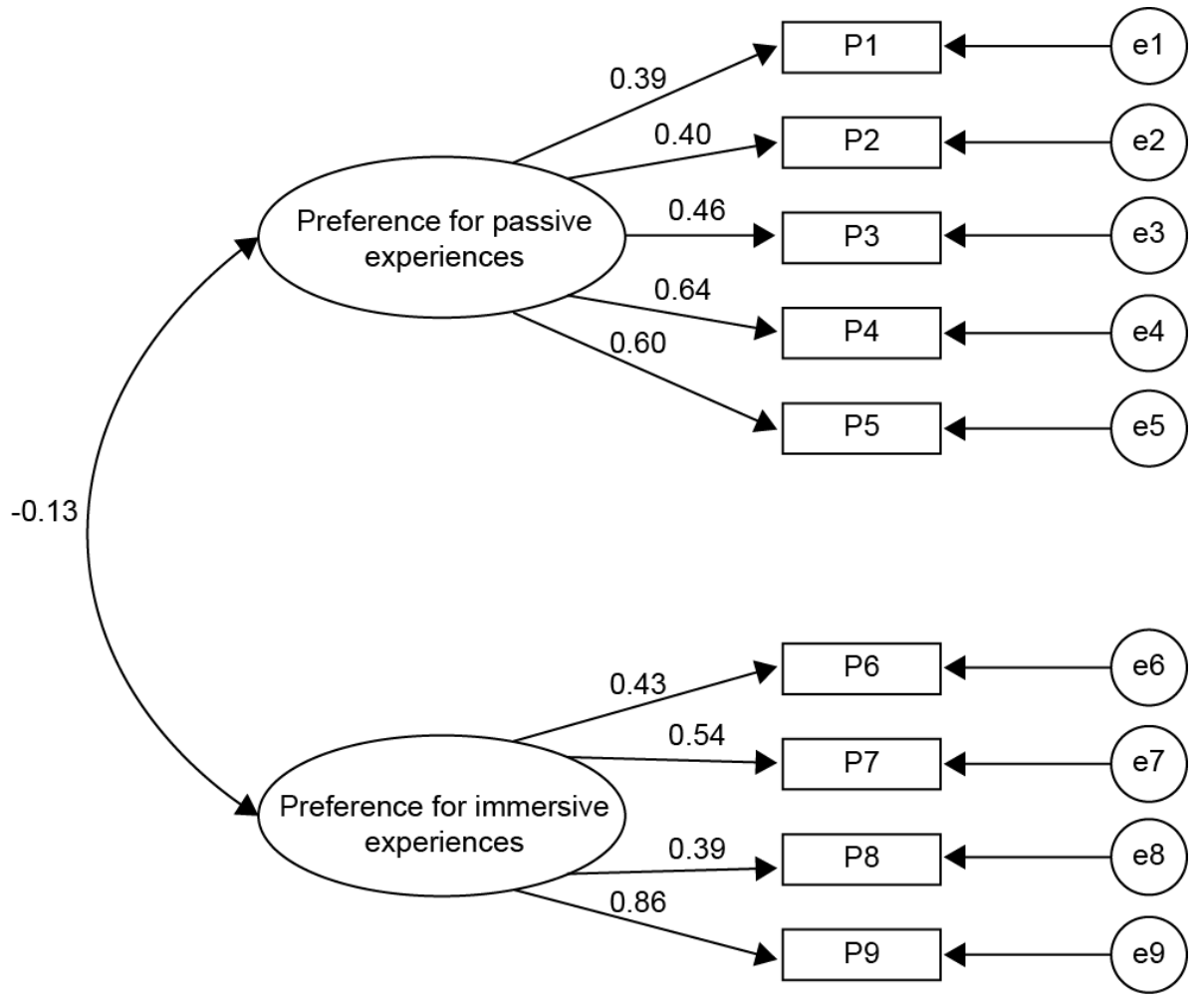

